\title{
Structural and Rank Analysis as a Method of Regional Economic Sustainability Assessment
}

\author{
Natalia Buletova \\ Volgograd Institute of Management The branch of the \\ Russian Academy of National Economy and Public \\ Administration \\ Chair of State and Municipal Government \\ Volgograd, Russia \\ buletovanata@gmail.com
}

\author{
Igor Zlochevsky \\ Volgograd Institute of Management The branch of the \\ Russian Academy of National Economy and Public \\ Administration \\ Chair of State and Municipal Government \\ Volgograd, Russia \\ i_zlochevsky@mail.ru
}

\begin{abstract}
In accordance with Structural change theory by Fischer-Clark and with the tendency to expand intangible services sector and manufacturing industries in the inter-sectoral structure of the regional economy, this paper presents authors' proposals to improve the method of structural and rank analysis in regional economic sustainability assessment. The classification of the regions on the basis of specific calculations which applies a differentiated approach to strategic planning and management methods makes it possible to increase the achievability of strategic objectives of regional development for the subjects of the Russian Federation with different types of economic structure.
\end{abstract}

Keywords-industrialization, service, structural changes, effective ranking, types of economic structure

\section{INTRODUCTION}

Development of an effective monitoring and evaluation system in the Russian public sector is considered to be an important part of the public strategic planning. Despite this fact, Russian Federal Law No. 172-FZ does not give an unambiguous interpretation of the purpose and means of such monitoring. The common practice nevertheless shows that the law is interpreted primarily as the requirement to assess quantitative results of the strategic measures implementation. We believe that it is equally important to analyze qualitative characteristics of structural changes in the social and economic environment which ensure the minimum necessary and sufficient levels of sustainability of these processes.

With regard to the above mentioned, we assess the role of the state in interaction with market institutions and in managing the trajectory of regional development as well as its ability to use tools to update economic systems at meso- and micro levels. it is important to ensure that decision-making in managing of regional economy or regulating enterprises` economic activity accounts of service and digital economy trends on national and global levels as well as of priorities of federal economic development by effective analytics. The latter includes the models developed on the basis of the theory of structural changes by Fisher-Clark concerning the measurement of inter-sectoral proportions in gross value added (GVA), their comparison, juxtaposition and contrast, to evaluate the trajectory rate of the changes in terms of increase in quality of industrial manufacturing, production of goods and services, comparison of the results obtained for the subjects of the Russian Federation, classification on the basis of the effective ranking, the type and the level of sustainable social and economic development.

According to O.S. Sukharev, effective approach to the structural analysis of the national economy includes systemic calculation of the following indicators:

- Structural shift bulk is referred to as the difference in the share of the structural indicator in the current and in the reference period [1];

- Structural shift index as the ratio of the structural shift bulk to the base value of the economic indicator for a certain period of time, expressed as a percentage [2]; the UN methodology defines the structural shift index as the ratio of the amount of the difference in the shares of growing sectors in production, employment and investments, at a certain moment of time and at the initial moment of time, to the number of growing sectors multiplied by the total duration of time [3, P.82];

- Structural shift rate is the ratio of the structural shift bulk to the time interval at which it occurs [1];

- Structural dependency ratio (is also known as coefficient of exports to imports) [4, P.31].

When analyzing ranking of objects arranged in rating order, we observe some significant drawbacks in reflection of rating evaluations results, Firstly, when the nonlinearity of the distribution of ranking objects is not taken into account. Secondly, when objects, for instance, regions and their economic systems differ significantly among themselves by the ranked indicator and occupy a certain place in the final rating out of the total number of 85 subjects of the Russian Federation but the degree of difference between them in 
particular between those occupying adjacent places is not taken into account.

\section{MATERIALS AND Methods (MODEL)}

We conducted structural and ranking analysis in a particular order and applied such methods as:

1) Statistical indicators of coordination $t_{i}$ are calculated by comparing such sectors of the regional economy as agricultural $\left(D_{A}\right)$, industrial $\left(D_{I}\right)$, service $\left(D_{U}\right)$. The calculated $t_{i}$ indicators reflect the result of the ratio of the obtained $D_{i}$ in the following optional situatons:

$$
\begin{gathered}
t_{\alpha}=D_{I} / D_{A} \\
t_{\beta}=D_{U} / D_{I}
\end{gathered}
$$

For the first time, a similar approach to structural analysis was applied in [5]. In the course of the study, we determined that the greater the values of the basic $t_{\alpha}$ and $t_{\beta}$ exceed the value of 1 , the more developed and sustainable the economy is considered to be. Therewith, its structural changes indicators over a certain period are taken into account and such economy is referred to as one with developed industrial and service sectors.

2) in order to identify and classify economic development types based on structural analysis, the authors compiled a matrix (Table 1). It provides a new classification of countries and regions in terms of the level of economic development and the quality of structural changes occurring in dynamics.

\begin{tabular}{|c|c|c|c|c|c|}
\hline \multicolumn{6}{|c|}{ SECTORAL PROPORTIONS } \\
\hline \multirow{2}{*}{\multicolumn{2}{|c|}{$\begin{array}{l}\text { Inter-sectoral } \\
\text { proportions } \\
\text { (stages of } \\
\text { economic } \\
\text { development) }\end{array}$}} & \multirow{2}{*}{$\begin{array}{c}D_{A}>D_{I} \\
\text { (agrarian } \\
\text { type) }\end{array}$} & \multirow{2}{*}{$\begin{array}{c}D_{I}>D_{A} \\
\text { (industrial } \\
\text { type) }\end{array}$} & \multicolumn{2}{|c|}{ Including: } \\
\hline & & & & $\begin{array}{c}D_{\text {оп }}> \\
D_{\text {дпи }}\end{array}$ & $\begin{array}{c}D_{\text {дпи }}> \\
D_{\text {оп }}\end{array}$ \\
\hline \multicolumn{2}{|c|}{$\begin{array}{c}D_{T}>D_{U} \\
\text { (industrial type) }\end{array}$} & $\begin{array}{c}\text { INDUSTRIA } \\
\text { L- } \\
\text { AGRARIAN } \\
\text { TYPE }\end{array}$ & $\begin{array}{l}\text { INDUSTRIA } \\
\text { L TYPE }\end{array}$ & $\begin{array}{c}\text { HIGHLY } \\
\text { DEVELOP } \\
\text { ED } \\
\text { INDUSTRI } \\
\text { AL TYPE } \\
\end{array}$ & $\begin{array}{c}\text { RAW } \\
\text { MATERIA } \\
\text { L } \\
\text { INDUSTRI } \\
\text { AL TYPE } \\
\end{array}$ \\
\hline \multicolumn{2}{|c|}{$\begin{array}{c}D_{U}>D_{T} \\
\text { (service type) }\end{array}$} & $\begin{array}{c}\text { SERVICE- } \\
\text { AGRARIAN } \\
\text { TYPE } \\
\end{array}$ & $\begin{array}{l}\text { SERVICE- } \\
\text { INDUSTRIA } \\
\text { L TYPE } \\
\end{array}$ & & \\
\hline \multicolumn{2}{|c|}{ Including: } & & & & \\
\hline $\begin{array}{c}D_{N U}> \\
D_{M U} \\
\end{array}$ & $\begin{array}{c}D_{M U}> \\
D_{N U} \\
\end{array}$ & & & & \\
\hline $\begin{array}{c}\text { HIGHL } \\
\text { Y } \\
\text { DEVEL } \\
\text { OPED } \\
\text { SERVIC } \\
\text { E TYPE }\end{array}$ & $\begin{array}{l}\text { MATER } \\
\text { IAL } \\
\text { SERVIC } \\
\text { E TYPE }\end{array}$ & & & & \\
\hline
\end{tabular}

TABLE 1. MATRIX OF TYPES OF ECONOMIC SYSTEMS BY INTER-

This matrix allocates new sectors and industries identified in the structure of gross value added:

- the share of Extraction of Mineral Resources $D_{E M R}$ and the share of Manufacturing Production $D_{O \Pi}$ in the GVA;

- the share of Goods Manufacturing sector $D_{G}$ in the GVA;
- the share of Material Services Manufacturing $D_{M S}$ and the share of intangible services Manufacturing $D_{I S}$ в in the GVA.

3) the method of effective ranking was developed by the authors and is protected by copyright certificate of Russian state registration of the computer program No. 20107619388 "Calculation of the effective objects ranking by the values of their parameter".

Let us dwell on the main stages of the effective method of ranking included in the structural and rank analysis of regional economies and partly presented in previous publications of the authors, for example, [7]:

- A line trend sector is identified in the developed database of ranked objects. The sector is aligned in accordance with the most uniformly varying values of the indicators included in the applicable rating (with the maximum value of the determination coefficient $R^{2}$ );

- The variation range is calculated:

$$
R=x_{\text {max }}-x_{\text {min }}
$$

- The linear rank distribution is modeled:

$$
L R D=x_{\min }+(i-1) * h
$$

where $\mathrm{i}=1, \ldots, \mathrm{n}-$ rank $r$ of the ranking object (subjects of the Russian Federation, countries of the world);

$$
h=R /(\mathrm{n}-1) \text {. }
$$

- we make an isomorphic mapping of the non-linear structure of values of the indicator selected for ranking in the corresponding structure of positive integers:

$$
Y=k \times r+a_{0}
$$

where $Y$ is the ranking indicator;

$k$ is the linear coefficient;

$r$ - rank of the region;

$a_{0}$ is the intercept term.

- when substituting $Y$ with empirical values of the ranked indicator in the previous equation and resolving it with respect to the rank $r$, we obtain the following expression for its determination:

$$
r=\text { Integer }\left[\frac{y-a_{0}}{k}\right]
$$

where Integer (argument) is a function that rounds its argument to the nearest smaller integer value.

- the formula $Y=k \times r+a_{0}$ is transformed into the formula to calculate the effective rank $r^{*}$ where the parameters of the line equation calculated from a linear interval substitute $k$ and $a_{0}$;

- shifting the minimum rank to a value of 1 is an additional procedure for arranging efficient rank values for all ranking objects;

- classification of the ranking objects to ensure the most correct distribution and interpretation of the rating results.

The approbation results obtained in the course of structural and rank analysis approved by the authors, made it possible to reinterpret the state of economic systems of the subjects of the Russian Federation in a new way. We took into account the structures and the structural changes that are taking place in 
the subjects, as well as the actual position in the aggregate rating of objects, results of its social, environmental and economic development as well as the uneven development and disproportions in resource provision.

The application of this method as a new statistical methodology to analyze objects of any scale or the method of economic analysis at the micro-level opens wide prospects for its use. It also provides an alternative approach to assessment of territories (or enterprises) in order to determine their sustainability level, quality of management of the growth process and the prospects for further development in compliance with the strategic target.

\section{RESULTS AND DISCUSSION}

We took the example of the Volgograd region as one of the most problematic from the point of view of the results of economic development over the entire period of modern Russia. The Volgograd region lost the status of industrially developed territory and its strategic priority for future sustainability lies in the development of agricultural sector. Fig. 1 shows the result of the $t_{\alpha}$ and $t_{\beta}$ ratio over 2004-2015 period, according to the Federal State Statistics Service "Branch structure of the gross added value of the subjects of the Russian Federation".

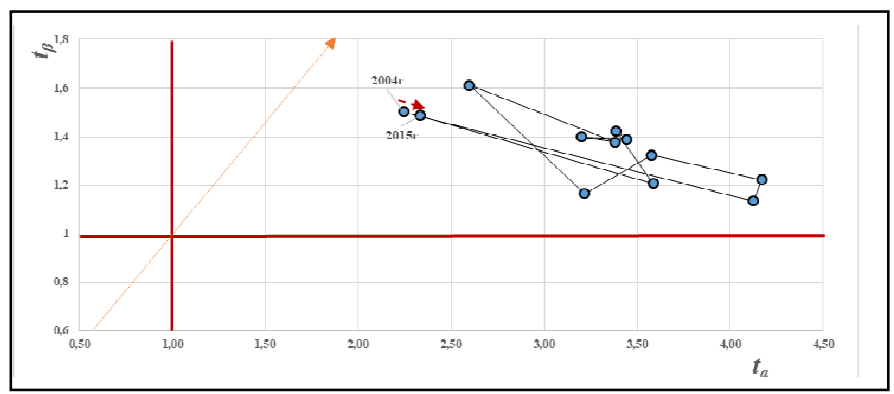

Fig.1 Structural shift trajectory from $t_{\beta}$ to $t_{\alpha}$ in the Volgograd region economic system over 2004-2015 period.

The results of structural and rank analysis can be divided into the following parts:

\section{A. Distribution of Subjects of the Russian Federation is based on the Structural Analysis Results}

We calculated the coordination indicators $t_{\alpha}$ and $t_{\beta}$ for all the subjects of the Russian Federation, and the following graphic regional distribution was produced according to the level of economic development, taking into account the intersectoral division of the gross added value of the regional economy (Fig. 2).

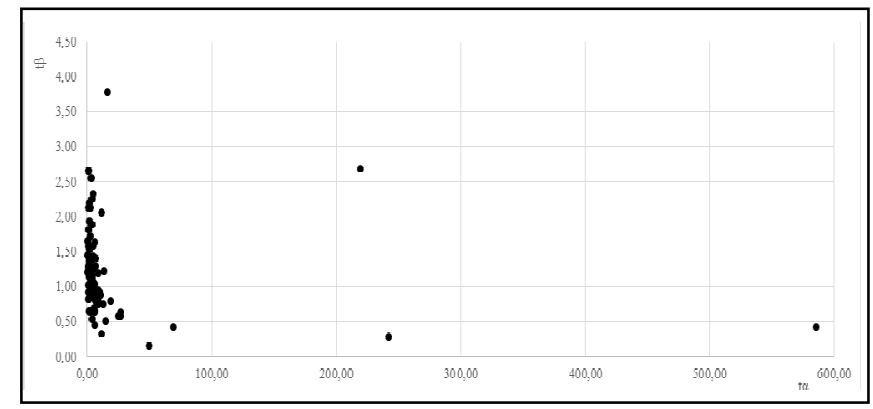

Fig.2. The $t_{\alpha}$ and $t_{\beta}$ ratio according to the sectoral structure of the subjects of the Russian Federation in 2015

Source: compiled by the authors using the data of the Federal State Statistics Service "Sectoral structure of the subjects of the Russian Federation in 2015"

The authors of the paper conducted an internal scaling of the calculated values of $t_{\alpha}$ and $t_{\beta} \operatorname{t\alpha } \mathrm{t} \beta$ (Fig. 3) and obtained the following characteristics of the types of regional economy on the basis of its structure and compositional changes that determine the nature of sustainability of social and economic development and the vector of future structural changes for the steady economy quality growth.

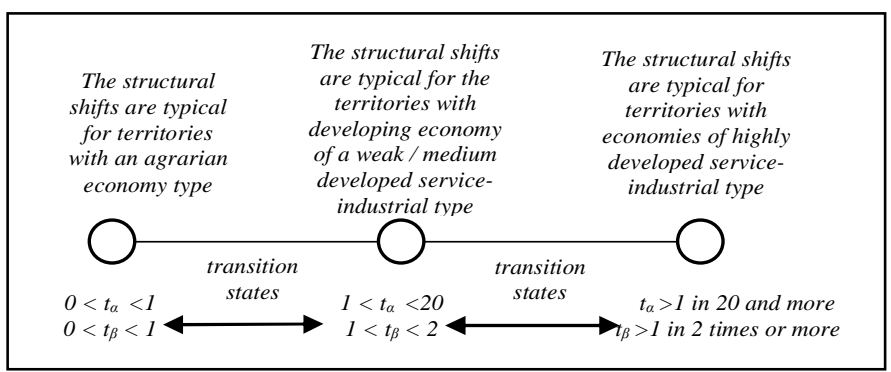

Fig.3 An example of scaling and interpreting the values of $t \alpha$ and $t \beta$ in the developed typology [6]

We defined the first type of economy as zero, it is typical for territories with $t_{\alpha}$ and $t_{\beta}<1$, this type of economy is referred to as agrarian, that is, economically under-developed. Table 2 shows the result of the distribution of the subjects of the Russian Federation according this typology. Reported by the Federal State Statistics Service in 2015, two regions of the country had this type of economy: the Karachay-Cherkess Republic and the Tambov Region.

The second type of economy (A) is defined by the authors as less-developed within which it is possible to point out:

- Subtype A1 is typical for territories in the structure of economy of which there are values $t_{\alpha}<1$ and $t_{\beta}>1$ (agrarianservice type);

- Subtype A2 is typical for economy structure which includes values for its territories within $t_{\alpha}>1$ and $t_{\beta}<1$ (agrarian-industrial type);

The third type (B) is defined in the study as a steadily developing economy for which an internal division into subtypes is done through the following categories:

- subtype B1 is typical for territories with values $1<t_{\alpha}<20$ and $1<t_{\beta}<2$ (service-industrial type with a priority 
development on the service sector in comparison with the production of goods);

- subtype B2 is typical for territories with the values $10<t_{\alpha}$ $<20$ and $1<t_{\beta}<2$ (industrial-service type with priority development on the industrial production sector);

According to our reckoning, marking the intervals $t_{\alpha}$ and $t_{\beta}$ is not enough; expert analysis is needed assuming that the complex task of allocating regions by selected types becomes automated.

Such a large scale of values $t_{\alpha}$ and $t_{\beta}$ is due to the different intensity of development and expansion of the industrial and service sectors of the regional economy. We made similar calculations for a number of highly economically developed western countries (such as Germany and Japan) that show the growth rates of industrialization is more visible and more significant in dynamics than the increase in the service level.

Another example of scaling is possible, requiring not only empirical confirmation but also theoretical justification.

The fourth type (C) is defined by the authors as a highly developed economy, the division into subtypes $\mathrm{C} 1$ and $\mathrm{C} 2$ has the following interpretations:

- subtype C1 is typical for territories with values $1<t_{\alpha}<40$ and $2<t_{\beta}<4$ (service-industrial type of the next level of stability of social and economic development following type B);

- sector C2 is typical for territories with values $20<t_{\alpha}<40$ and $1<t_{\beta}<4$ (industrial-service type of higher level of development and sustainability).

The fifth type (D) is typical for territories with the most intensive and sustainable economic development that can occur in modern economic systems, the following division into subtypes D1 and D2 is proposed:

- subtype D1 is typical for territories in the structure of the economy of which there are values $1<t_{\alpha}<60$ and $4<t_{\beta}<6$;

- sector D2 is typical for territories, in the structure of the economy there are values $40<t_{\alpha}<60$ and $1<t_{\beta}<6$.

The calculations and classification was applied to the subjects of the Russian Federation (according to the structure of gross added value in 2015), the following results were obtained for the distribution of regional economies by structure and achieved level of economic development (Table 2). Distribution of RF subjects according to 2015
TABLE 2. Result of distribution of the subjects of the Russian Federation by types of economic systems

\begin{tabular}{|c|c|c|}
\hline $\begin{array}{l}\stackrel{\Xi}{\Xi} \\
\stackrel{\Xi}{\Xi} \\
\stackrel{\Xi}{E}\end{array}$ & \begin{tabular}{|} 
Distribution of the \\
subjects of the \\
Russian \\
Federation in \\
2015
\end{tabular} & The list of subjects of the Russian Federation \\
\hline Zero & $\begin{array}{l}2 \text { subjects of the } \\
\text { Russian } \\
\text { Federation }\end{array}$ & Karachay-Cherkess Republic, the Tambov region \\
\hline A1 & $\begin{array}{l}6 \text { subjects of the } \\
\text { Russian } \\
\text { Federation }\end{array}$ & $\begin{array}{l}\text { the Orlov region, Chechen Republic, North } \\
\text { Ossetia-Alania, the Republic of Altai, the } \\
\text { Republic of Dagestan, the Republic of Kalmykia }\end{array}$ \\
\hline $\mathrm{A} 2$ & $\begin{array}{l}34 \text { subjects of } \\
\text { the Russian } \\
\text { Federation }\end{array}$ & $\begin{array}{l}\text { the Yamal-Nenets Autonomous District, the } \\
\text { Khanty-Mansiysk Autonomous District, the } \\
\text { Nenets Autonomous District, the Republic of } \\
\text { Sakha (Yakutia), the Komi Republic, the } \\
\text { Chukotka Autonomous District, the Perm } \\
\text { Territory, the Krasnoyarsk Territory, the } \\
\text { Kemerovo Region, the Sakhalin Region, Tomsk } \\
\text { Region, the Vologda Region, the Republic of } \\
\text { Khakassia, the Magadan Region, the Irkutsk } \\
\text { Region, the Tula Region, Chelyabinsk Region, } \\
\text { the Orenburg Region, the Republic of Tatarstan, } \\
\text { the Udmurt Republic, the Novgorod Region, the } \\
\text { Leningrad Region, the Republic of } \\
\text { Bashkortostan, the Kaluga Region, the Astrakhan } \\
\text { Region, the Omsk Region, the Lipetsk Region, } \\
\text { the Volgograd Region, the Saratov Region, the } \\
\text { Republic of Mordovia, Kursk Region, the } \\
\text { Republic of Mari El, Belgorod region }\end{array}$ \\
\hline B1 & $\begin{array}{l}32 \text { subjects of } \\
\text { the Russian }\end{array}$ & $\begin{array}{l}\text { the Nizhny Novgorod Region, the Tyumen } \\
\text { Region (without Khanty-Mansiysk Autonomous } \\
\text { District and Yamalo-Nenets Autonomous } \\
\text { District), the Yaroslavl Region, the Republic of } \\
\text { Karelia, Vladimir Region, Smolensk Region, } \\
\text { Republic of Buryatia, Ulyanovsk Region, Tver } \\
\text { Region, Arkhangelsk Oblast without JSC, } \\
\text { Kaliningrad Oblast, Kirov Region, Amur Region, } \\
\text { Khabarovsk Territory, Ryazan Region, Kostroma } \\
\text { Region, Murmansk Region, Chuvash Republic, } \\
\text { Kurgan Region, Pskov Region, Rostov Region, } \\
\text { Penza Region, Bryansk Region, Krasnodar the } \\
\text { Republic of Adygea, the Altai Territory, the } \\
\text { Voronezh Region, the Jewish Autonomous } \\
\text { Region, the Stavropol Territory, the Kamchatka } \\
\text { Territory, the Republic of Crimea, the } \\
\text { Kabardino-Balkarian Republic }\end{array}$ \\
\hline $\mathrm{B} 2$ & $\begin{array}{l}1 \text { subject of the } \\
\text { Russian } \\
\text { Federation }\end{array}$ & The Sverdlovsk region \\
\hline $\mathrm{C} 1$ & $\begin{array}{l}8 \text { subjects of the } \\
\text { Russian } \\
\text { Federation }\end{array}$ & $\begin{array}{l}\text { Moscow, the Moscow Region, the Ivanovo } \\
\text { Region, the Trans-Baikal Territory, the } \\
\text { Novosibirsk Region, the Republic of Tyva, the } \\
\text { Republic of Ingushetia, the Primorye Territory }\end{array}$ \\
\hline $\mathrm{C} 2$ & $\begin{array}{l}1 \text { subject of the } \\
\text { Russian } \\
\text { Federation, }\end{array}$ & St. Petersburg \\
\hline D1 & $\begin{array}{l}1 \text { subject of the } \\
\text { Russian } \\
\text { Federation, }\end{array}$ & city of Sevastopol \\
\hline
\end{tabular}

In order to present a complex characteristic of the type of economic system based on the basic inter-sectoral relations $t_{\alpha}$ and $t_{\beta}$ let us study the examples of the constituent entities of the Russian Federation included in the Southern Federal District: 
1) the Kalmyk Republic has agrarian-service (nonindustrial) type A1 $\left(t_{\alpha}=0,15\right)$ with priority development of the service sector $\left(t_{\beta}=1,21\right)$. The development trend lies in manufacturing and non-material services; there is a transition to type $\mathrm{A} 2$ or $\mathrm{B} 1$ with increasing $t_{\alpha}$.

2 ) the Astrakhan region has industrial (raw) type $\mathrm{A} 2,\left(t_{\alpha}=\right.$ $4,1)$ with priority development of the service sector $\left(t_{\beta}=0,98\right)$. The development trend is defined as manufacturing and nonmaterial services; the transition to type B1 or B2 is observed with increasing $t_{\beta}$.

3) the Volgograd region is characterized by industrial (technologically advanced) type $\mathrm{A} 2, \quad\left(t_{\alpha}=2,33\right)$ with domination of production of goods over production of services $\left(t_{\beta}=0,85\right)$. The development trend is defined as industrial production and non-material services development; there io a transition to type $\mathrm{B} 1$ or $\mathrm{B} 2$ with increasing $t_{\alpha}, t_{\beta}$.

4) the Rostov region has service-industrial type B1 $\left(\mathrm{t}_{\alpha}=\right.$ 1,72 ), but the level of development of the service sector is not high $\left(\mathrm{t}_{\beta}=1,15\right)$. The development trend is concentrated on the industrial production and non-material services; transition to type $\mathrm{B} 2$ or $\mathrm{C} 1$ with increasing $t_{\alpha}, t_{\beta}$ is observed.

5) the Krasnodar area has service-industrial type B1, $\left(\mathrm{t}_{\alpha}=\right.$ $14,28)$, but the level of development of the service sector is not high $\left(\mathrm{t}_{\beta}=0.51\right)$. The development trend is prioritized in the sector of intangible services production; transition to type $\mathrm{B} 2$ or $\mathrm{C} 1$ with increasing $\mathrm{t}_{\beta}$ is observed.

6) the Republic of Adygea has service-industrial type B1, $\left(\mathrm{t}_{\alpha}=1,25\right)$ accompanied by a highly developed service sector $\left(t_{\beta}=1.39\right)$. The development trend is defined as: development of industrial production and non-material services; transition to type $\mathrm{B} 2$ or $\mathrm{C} 1$ with increasing $\mathrm{t}_{\alpha}$.

7) the Republic of Crimea has service-industrial type B1, $\left(\mathrm{t}_{\alpha}=1.05\right)$, accompanied by a high level of development of the service sector $\left(t_{\beta}=1.58\right)$. The development trend is concentrated on development of industrial production and non-material services; there is a transition to type $\mathrm{B} 2$ or $\mathrm{C} 1$ with increasing $\mathrm{t}_{\alpha}$.

8). the city of Sevastopol has the most developed serviceindustrial type $\mathrm{D} 1,\left(\mathrm{t}_{\alpha}=2,31\right.$ and $\left.\mathrm{t}_{\beta}=4,52\right)$. The development trend is defined as increasing industrial and intangible services production; transition to type D2 with increasing $t_{\alpha}$ is observed.

B. The distribution of Subjects of the Russian Federation is based on indicators of social and economic development with the use of effective rank method.

Support of ranking correlation conclusions with the results of structural analysis is an important condition to assess results of effective ranking of the subjects of the Russian Federation. Taking into account types distribution of regional economy in terms of the structural changes and their classification presented in Table 2, we developed a variant of classification of subjects of the Russian Federation for the purpose of ranking:

- Type I is a group of territories that occupy leading positions in the field of economic, cultural, tourist, social development and includes economies classified as types D and C;

- Type II is a group of highly industrialized territories, being included in economies classified as type B;

- Type III is a group of commodity economies classified as type A2;

- Type IV is a group of agrarian economies classified as type A1;

- Type V is a group of highly subsidized territories with underdeveloped economies (zero type).

The example of the rank indicator of social and economic development of the constituent entities of the Russian Federation referred to as "Investments in fixed capital per capita" was used to calculate the effective rank and multi-level distribution of rating objects on the basis of 5 distinguished types:

- 10 subjects of the Russian Federation of the 1st type are distributed according to effective ranks from 1 to 17 . This indicates their high "homogeneity" in terms of investment attractiveness (Fig. 4);

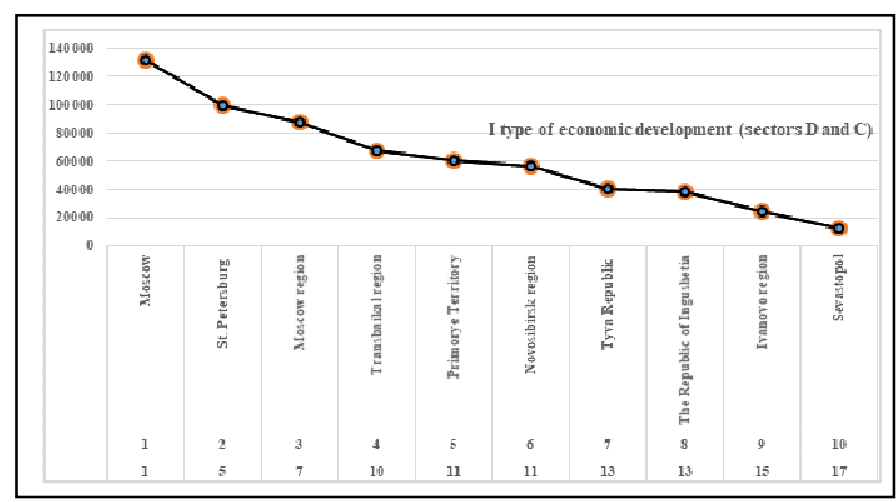

Fig.4 Ranking of type I subjects of the Russian Federation

The other subjects of the Russian Federation have been similarly ranked and ranged for example:

- 33 subjects of the Russian Federation of type II are distributed according to effective ranks from 1 to 84 . The amplitude of effective rank which is 3 times greater than the number of ranged objects can be explained by high degree of irregularity of the regional development;

- 34 subjects of the Russian Federation of type III are distributed according to effective ranks from 1 to 874 , the degree irregularity of the regional development is more significant, as is the social and economic state of the regions;

- 6 subjects of the Russian Federation of type IV are distributed according to effective ranks from 1 to 7 . This is the indicator of their similar investment attractiveness and correctness of the proposed approach to the multilevel distribution of rating objects and subsequent ranking of the results obtained;

- 2 subjects of the Russian Federation of type $\mathrm{V}$ can be attributed to zero type. 


\section{CONCLUSION}

Taking into consideration the fact that both conducted structural evaluation and rank analysis have provided similar interrelated results in respect to their contents and sequence, we come to conclusions that ranking outcomes should reflect features of the content and application according to the given correlation:

1. Using traditional statistical indicators of coordination and the rules of inter-sectoral correlation in the structure of gross added value, the authors have justified the way of calculating and interpreting the results of this approach to the structural analysis of the regional economy. The main result of the new approach was intersectoral relationships classification of the economy. The findings and results of the structural analysis of regional social and economic systems are certainly useful for the purposes of strategic monitoring of regional development, as well as for assessing the quality of state strategic planning and implementing structural economic policies.

2. We developed an algorithm to calculate the effective rank for determining the position of each region in the aggregate rating. Besides, the algorithm can be used to analyze the hierarchy and structural changes in the regional economies, as well as a method to assess the degree of stability / instability of its social and economic development with respect to its unevenness or nonuniformity.

The correlation between the types of economies obtained through structural analysis and multilevel rating, presented by the authors, makes it possible to increase accuracy and interpretational quality of such information. The correlation provides the state with an effective methodological tool to monitor the sustainability results of strategic management of the social and economic development of Russian regions. More than that, potential investors and any party interested in the information correctly reflecting the degree of economic development and its stability, can resolve to the method to assess strategic objectives and priorities of development.

\section{References}

[1] O.S. Sukharev, "Structural problems of the Russian economy: theoretical justification and practical solutions" [Strukturnye problemy ekonomiki Rossii: teoreticheskoe obosnovanie $i$ prakticheskie resheniya]. Moscow, Finance and Statistics Publ., 2010, 192 p.

[2] O. Yu. Krasilnikov, "Structural shifts in the economy of modern Russia" [Strukturnye sdvigi $v$ ekonomike sovremennoi Rossii]. Saratov: Publishing House "Scientific Book", 2000, 183 p.

[3] O.S.Sukharev, and O.B. Ilyina, "Analysis of the dynamics of structural changes in the regional economic system, such as a special economic zone" [Analiz dinamiki strukturnykh sdvigov regional'noi ekonomicheskoi sistemy tipa osoboi ekonomicheskoi zony]. Bulletin of the SRSTU (NPI). Series: social and economic sciences [Vestnik YuRGTU (NPI). Seriya: Sotsial'no-ekonomicheskie nauki], 2012, vol. 4, pp. 79-100.

[4] O.S. Sukharev, "Structural analysis and structural changes in the Russian economy" [Strukturnyi analiz i strukturnye izmeneniya ekonomiki Rossii]. Investments in Russia [Investitsii v Rossii], 2013, vol. 1, pp. 29-35.

[5] O.V. Inshakov, I.V. Sharkevich, and A.V. Shevandrin, "Analysis of structural changes and prospects for the development of regional economic systems" [Analiz strukturnykh izmenenii i perspektiv razvitiya regional'nykh ekonomicheskikh sistem]. Bulletin of Volgograd State University. Series 3: The Economy. Ecology [Vestnik Volgogradskogo gosudarstvennogo universiteta. Seriya 3: Ekonomika. Ekologiya], 2006, vol. 10, pp. 56-67.

[6] N.E.Buletova, and E.V. Stepanova, "Structural differences of economies of different developmental types: assessments and effective ranking on a global basis," International Journal of Applied Engineering Research, 2017, Vol. 12, no.22, pp. 12554-12563.

[7] N.E.Buletova, and I.V.Sharkevich, "Rank analysis of regional social and economic systems: improved approach" [Rangovyi analiz regional'nykh sotsial'no-ekonomicheskikh sistem: usovershenstvovannyi podkhod]. Economic Analysis: Theory and Practice [Ekonomicheskii analiz: teoriya i praktika], 2016, vol. 10 (457), pp. 17-27. 